\title{
STUDI TUMBUHAN SUMBER PAKAN MONYET EKOR PANJANG (Macaca fascicularis) DI KAWASAN YOUTH CAMP TAMAN HUTAN RAYA WAN ABDUL RACHMAN LAMPUNG
}

\section{STUDIES ON PLANT FOOD SOURCE OF LONG-TAILED MACAQUE (Macaca fascicularis) AT YOUTH CAMP AREA OF THE WAN ABDUL RAHMAN GREAT FOREST PARK LAMPUNG}

\author{
Bona Quinda ${ }^{1}$, M. Kanedi ${ }^{1}$, Nuning Nurcahyani ${ }^{1}$, Ronald HP Panjaitan ${ }^{2}$ \\ ${ }^{1}$ Jurusan Biologi FMIPA Universitas Lampung \\ ${ }^{2}$ Dinas Kehutanan Provinsi Lampung \\ e-mail : bona.quinda@yahoo.co.id \\ Jurusan Biologi FMIPA Universitas Lampung \\ J. Prof.Dr. Soemantri Brojonegoro No. 1, Bandar Lampung, Lampung, Indonesia, 35145
}

\begin{abstract}
Abstrak
Jenis pakan monyet ekor panjang dapat berupa daun, buah, biji, bunga, serangga, dan telur burung. Tujuan penelitian ini adalah untuk mengetahui jenis-jenis tumbuhan dan bagian tumbuhan yang digunakan sebagai sumber pakan monyet ekor panjang serta lokasi tempat mencari makan. Penelitian ini dilaksanakan dari bulan Agustus sampai dengan September 2012 di kawasan Youth Camp Taman Hutan Raya Wan Abdul Rachman Lampung. Penelitian ini menggunakan metode observasi. Terdapat 10 jenis tumbuhan yang menjadi sumber pakan monyet ekor panjang, yaitu dahu (Dracontomelon dao Merr. Et Rolfe.), hampelas (Ficus tinctoria), bayur (Pterospermun javanicum), waluhan (Cucurbitaceae), waru (Hibicus tiliaceus), keranji (Dalium plattysepalum), bambu (Bambusa sp.), matoa (Pometia pinnata J. R. \& G.Forst.), nangka (Arthocarpus integra), dan melinjo (Gnetum gnemon). Bagian pohon yang dimakan berupa buah, daun dan bunga.
\end{abstract}

Kata kunci : monyet ekor panjang, jenis pakan

\begin{abstract}
Food of Long-tailed macaques are leaves, fruits, seeds, flowers, insects, and bird's egg. The purposes of the research were to identify the types of plants and parts of plants used as food source as well as the long-tailed macaques foraging locations. The study was carried out from August to September 2012 at Youth Camp area of the Wan Abdul Rachman Great Forest Park Lampung. Based on the intensive observation, there are 10 species of plants used as the source food by long-tailed macaque include dahu (Dracontomelon dao Merr. Et Rolfe.), hampelas (Ficus tinctoria), bayur (Pterospermun javanicum), waluhan (Cucurbitaceae), waru (Hibicus tiliaceus), keranji (Dalium plattysepalum), bambu (Bambusa sp.), matoa (Pometia pinnata J. R. \& G.Forst.), nangka (Arthocarpus integra), dan melinjo (Gnetum gnemon). The common parts of plant consumed by the macaque are fruits, leaves and flowers.
\end{abstract}

Key words : Long tailed-macaques, kind of food.

\section{PENDAHULUAN}

Dalam mencari makan Monyet ekor panjang selalu merubah daerah jelajahnya, tergantung pada ketersediaan makanan. Monyet ekor panjang pada dasarnya bersifat herbivor dengan makanan utamanya berupa buah. Kriteria buah yang dipilih oleh monyet biasanya berdasarkan warna, bau, berat buah, dan kandungan nutrisi. Selain buah, jenis makan-an yang biasa dikonsumsi monyet ekor pan-jang adalah daun, umbi, bunga biji, dan se-rangga (Farida, 2008).
Sutardi (1980) menjelaskan bahwa penciuman merupakan indera utama dalam mencari pakan oleh seekor hewan. Saat memilih pakan, seekor hewan dengan nalurinya akan memilih bahan pakan yang tinggi nilai gizinya, tidak membahayakan kesehatannya, memiliki bau, dan cita rasa yang sesuai.

Secara umum monyet ekor panjang cenderung menguasai makanan sebanyak mungkin walaupun tidak mampu menghabiskan semuanya. Banyaknya makanan yang dikumpulkan berhubung- 
an dengan keinginannya untuk dapat menunjukkan kekuatannya terhadap individu lain. Seringkali hal ini memicu terjadinya perkelahian. Bila ada makanan yang lebih disukai maka monyet ekor panjang akan meninggalkan makanan sebelumnya (Setyawan, 1996).

Taman Hutan Raya Wan Abdul Rachman merupakan salah satu kawasan konservasi di Provinsi Lampung yang dihuni populasi monyet ekor panjang cukup banyak. Kawasan ini memiliki luas $22.249,31$ ha. Saat ini, kondisi kawasan tersebut telah banyak berubah fungsi menjadi area perkebunan sehingga menyebabkan menyempitnya habitat alami, dan secara tidak langsung mengurangi jumlah pakan alami dari monyet ekor panjang tersebut. Tujuan penelitian ini adalah untuk mengetahui jenis-jenis dan bagian tumbuhan yang digunakan sebagai sumber pakan monyet ekor panjang.

\section{BAHAN dan METODE}

Penelitian ini telah dilaksanakan dari bulan Agustus sampai dengan September 2012 di kawasan Youth Camp Taman Hutan Raya Wan Abdul Rahman Lampung. Penelitian ini menggunakan metode observasi di lapangan dengan dengan alat bantu seperti teropong, kamera dan stop watch untuk mengamati aktivitas makan dari monyet ekor panjang. Data yang dikumpulkan berupa jenis tumbuhan sumber pakan, bagian tumbuhan yang dimakan dan lokasi tumbuhan pakan. Pengamatan dilakukan selama 15 menit perjam. Data dianalisis secara deskriptif dan ditampilkan dalam bentuk tabel.

\section{HASIL dan PEMBAHASAN}

Berdasarkan data yang diperoleh terdapat 10 jenis tumbuhan yang menjadi sumber pakan monyet ekor panjang dengan bagian yang dimakan berupa daun muda, buah, dan bunga. Monyet menyukai pakan daun muda dari beberapa pohon seperti bambu, bayur, hampe-las, melinjo dan matoa. Sedangkan buah dipe-roleh dari dahu, hampelas, keranji, melinjo dan nangka. Bunga dan kuncup bunga dipero-leh dari waru dan waluhan (Tabel 1).

Bagian tumbuhan yang paling disukai sebagai pakan bagi monyet ekor panjang adalah buah (Tabel 2), karena paling banyak ditemui sepert buah dahu, hampelas, nangka, dan waru. Pohon dahu merupakan tumbuhan yang dominan di kawasan Youth Camp sehingga buah yang dihasilkan menjadi sumer pakan monyet yang mudah diperoleh. Pohon digunakan oleh pri-mata bukan hanya sebagai sumber pakan tetapi juga sebagai tempat melakukan aktivitas lainnya seperti bermain, istirahat dan grooming karena karakteristik pohon dahu yang memiliki banyak cabang dan berdaun lebat serta letaknya dekat dengan aliran air.

Tabel 1. Jenis tumbuhan sebagai sumber pakan mo-nyet ekor panjang yang dapat ditemukan di hutan.

\begin{tabular}{|c|c|c|c|c|}
\hline No & $\begin{array}{c}\text { Nama } \\
\text { lokal }\end{array}$ & Famili & $\begin{array}{c}\text { Bagian yang } \\
\text { dimakan }\end{array}$ & FP \\
\hline 1 & Bambu & Gramineae & Daun muda & 6 \\
\hline 2 & Bayur & Malvaceae & Daun muda & 12 \\
\hline 3 & Dahu & Anacardiaceae & Buah & 150 \\
\hline 4 & Hampelas & Moraceae & $\begin{array}{c}\text { Daun muda } \\
\text { dan Buah }\end{array}$ & 31 \\
\hline 5 & Keranji & Resales & Buah & 7 \\
\hline 6 & Melinjo & Gnetaceae & $\begin{array}{c}\text { Daun muda } \\
\text { dan Buah }\end{array}$ & 3 \\
\hline 7 & Matoa & Sapindaceae & Daun muda & 5 \\
\hline 8 & Nangka & Moraceae & Buah & 4 \\
\hline 9 & Waru & Malvaceae & $\begin{array}{c}\text { Daun muda } \\
\text { dan Bunga }\end{array}$ & 10 \\
\hline 10 & Waluhan & Cucurbitaceae & $\begin{array}{c}\text { Kuncup } \\
\text { Bunga }\end{array}$ & 12 \\
\hline
\end{tabular}

Keterangan : FP) frekuensi pertemuan

Tabel 2. Tingkat kesukaan bagian tumbuhan yang dimakan

\begin{tabular}{|c|c|c|}
\hline No & $\begin{array}{c}\text { Bagian yang } \\
\text { dimakan }\end{array}$ & Tingkat kesukaan \\
\hline 1 & Buah & ++++ \\
\hline 2 & Daun & ++ \\
\hline 3 & Bunga & + \\
\hline \multicolumn{3}{|c|}{$\begin{array}{c}+++ \\
+\end{array}$} \\
\end{tabular}

Saat mencari makan ataupun bermain, satu kelompok monyet tidak hanya berada di satu pohon. Kelompok ini biasanya menyebar ke beberapa pohon tetapi pada jarak yang tidak terlalu jauh (Gambar 4 dan 5).

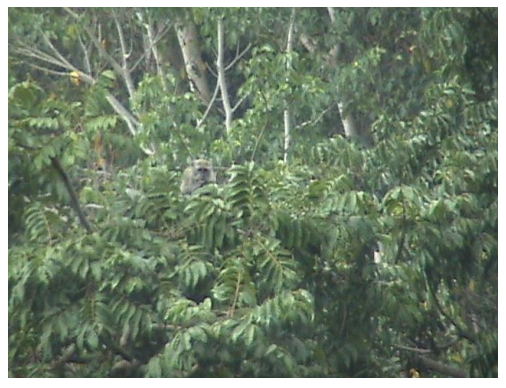

Gambar 4. Aktivitas makan monyet di pohon Dahu 


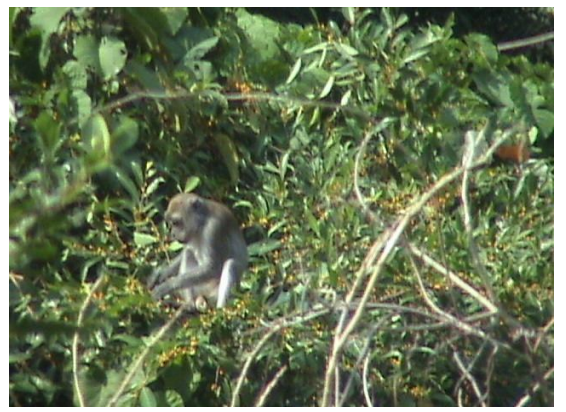

Gambar 5. Aktivitas makan monyet di pohon Hampelas

Di sekitar beberapa jenis pohon pakan ditemukan tanda sekunder berupa sisa-sisa pakan dari monyet ekor panjang (Gambar 3).

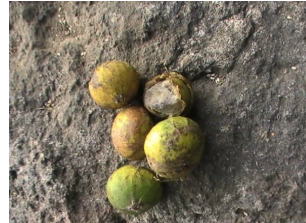

(a)

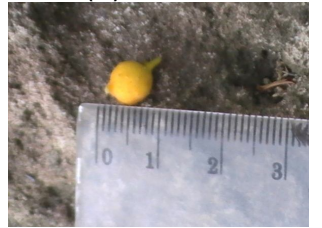

(c)

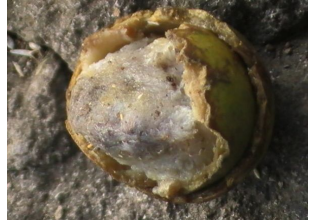

(b)

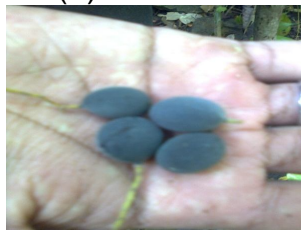

(d)
Gambar 3. Berbagai sisa pakan monyet ekor panjang (a) dan (b) buah dahu, (c) buah hampelas, (d) buah keranji

Beberapa jenis pohon juga digunakan sebagai sumber pakan oleh primata lain seperti cecah, satu kelompok lutung dan dua ekor siamang (Tabel 3).

Tabel 3. Pesaing monyet ekor panjang dalam mempe-roleh sumber pakan

\begin{tabular}{|c|c|c|}
\hline No & Pesaing yang Ditemui & $\begin{array}{c}\text { Nama } \\
\text { Pohon }\end{array}$ \\
\hline 1 & Cecah (Presbythis melalophos) & Bambu \\
\hline 2 & $\begin{array}{c}\text { Beruk (Macaca nemestrina) } \\
\text { Cecah (Presbythis melalophos) }\end{array}$ & Bayur \\
\hline 3 & $\begin{array}{c}\text { Cecah (Presbythis melalophos) } \\
\text { Siamang (Sympalangus syndactylus) }\end{array}$ & Dahu \\
\hline 4 & $\begin{array}{c}\text { Cecah (Presbythis melalophos) } \\
\text { Siamang (Sympalangus syndactylus) }\end{array}$ & Hampelas \\
\hline 5 & Siamang (Sympalangus syndactylus) & Keranii \\
\hline 6 & $\begin{array}{c}\text { Cecah (Presbythis melalophos) } \\
\text { Siamang (Sympalangus syndactylus) }\end{array}$ & Melinjo \\
\hline 7 & $\begin{array}{c}\text { Cecah (Presbythis melalophos) } \\
\text { Lutung (Trachypithecus auratus) }\end{array}$ & Matoa \\
\hline 8 & Beruk (Macaca nemestrina) & Nangka \\
\hline 9 & Cecah (Presbythis melalophos) & Waru \\
\hline 10 & Cecah (Presbythis melalophos) & Waluhan \\
\hline
\end{tabular}

Studi Tumbuhan Sumber Pakan Monyet Ekor Panjang / 46

\section{KESIMPULAN}

Ditemukan 10 jenis tumbuhan yang menjadi sumber pakan monyet ekor panjang. Bagian yang dimakan berupa buah, daun dan bunga, dengan bagian yang lebih banyak dimakan adalah buah.

\section{DAFTAR PUSTAKA}

Alikodra, H.S. 1990. Pengelolaan Satwa Liar. Jilid I. Departemen Pendidikan dan Kebudayaan Direktorat Jendral Pendidikan Tinggi. Pusat Antar Universitas IImu Hayati. IPB. Bogor.

Asnawi, E. 1991. Studi Sifat-Sifat Biologis Kukang (Nycticebus coucang). Skripsi. Fakultas Peternakan Intitut Pertanian Bogor. Bogor.

Bennet, B. T., R. C. Abee, and R. Henrickson. 1995. Nonhuman Primates in Biomedical Research Biology and Management. Academic Press. New York.

Brandon-Jones, D., A.A. Eudey, T.Geissmann, G.P. Groves, D.J. Melnick, J.C. Morales, M. Shekelle, C.B. Stewart. 2004. Asian Primate Classification. International Journal of Primatology 25: 97-104.

Chalmers, N. 1979. Social Behaviour in Primates. Contemporary Biology. Edward Arnold. London.

Cowlishaw.2004. How species respond to multiple extinction threats. Proc. R. Society. London. B 271, 1135-1141.

Dian R.W. 2001. Aktivitas Harian Monyet Ekor Panjang (Macaca fascicularis) dan Pengaruhnya Terhadap Pengelolaan Hutan Skripsi. Bogor: Jurusan Konservasi Sumberdaya Hutan Fakultas Kehutanan IPB.

Farida, H. 2008. Aktivitas Makan Monyet Ekor Panjang (Macaca fascicularis) di Bumi Perkemahan Pramuka Cibubur. Jakarta: Bogor. Skripsi. Departemen Biologi Fakultas Matematika dan IImu Pengetahun Alam Institut Pertanian Bogor.

Napier, J. R. and P. H. Napier. 1985. The Natural History of the Primates. The MIT Press, Cambridge, Massachussets.

Nasution, E.K., S.N.O., Swandyastuti dan Wiryanto. 2011. Aktivitas Harian dan Populasi Monyet Ekor Panjang (Macaca fascicularis) Di Kawasan Wisata Cikakak Wangon. Prosiding Seminar Nasional Hari Lingkungan Hidup. Fakultas Bilogi dan Peternakan Universitas Jenderal Soedirman Purwokerto, 
Putra, G.A., Sajuthi, D., dan Solihin, D.D..2010.Variasi Molekuler Gen Reseptor Melanokortin-4 pada Monyet Ekor Panjang. Jurnal Veteriner 11 (3):138-143.

Putra, I., Wandina, I., Soma, I., dan Sajhuti, D..2006.Indeks Massa Tubuh dan Morfometri Monyet Ekor Panjang (Macaca fascicularis) di Bali. Jurnal Veteriner 7:119124.

Rowe, N. 1996. The Pictorial Guide to The Living Primates. Pogonias Press. New York.

Santoso, Y. 1996. Beberapa Parameter Bioekologi Penting dalam Pengusahaan Monyet Ekor Panjang (Macaca fascicularis). Media Konservasi, 5 (1). Fakultas Kehutanan IPB: Bogor.

Sinaga, S., M., Pranoto U., Surono H., Archaitra N., A.. 2011. Pemanfaatan Habitat Oleh Monyet Ekor Panjang di Kampus IPB Darmaga Bogor. Departemen Konservasi Sumberdaya Hutan dan Ekowisata Fakultas Kehutanan IPB.

Setyawan, K. 1996. Interaksi Antara Monyet Ekor Panjang (Macaca fascicularis) dan Lutung (Prebitys cristata) di Taman Nasional Baluran. Malang: FMIPA Universitas Brawijaya.

Supriatna, J. dan E. Hendras W. 2000. Panduan Lapangan Primata Indonesia. Jakarta: Yayasan Obor Indonesia.

Ungar, P. 1995. Fruit preferences of four sympatric primate species at Ketambe, Northern Sumatra, Indonesia. International Journal of Primatology 16: 215-221.

Unit Pelaksana Tingkat Daerah Tahura. 2012. Taman Hutan Raya Wan Abdul Rachman. Bandar Lampung: UPTD Tahura WAR. 